\title{
Effect of Adding Magnesium Sulphate to Lidocaine, Bupivacaine and Hyaluronidase in Extraconal Block for Cataract Surgeries
}

\author{
Dalia Attia Abdelshafy Helal, Mohamed Anwar Refkee, Doaa Mohamed Farid, Ezzat Elshabrawi Galhom and \\ Osama Yehia A Khalifa*
}

Department of Anesthesia, Zagazig University, Egypt

Submission: August 20, 2018; Published: September 21, 2018

*Corresponding author: Osama Yehia A Khalifa, Department of Anesthesia, Zagazig University, Egypt, Tel: 00201007579438; Email: osamayehiaahmadkhalifa@gmail.com; yehia2001@hotmail.com

Abstract

Aim: This study is purpose to demonstrate the effectiveness of adding Magnesium Sulphate to Lidocaine, Bupivacaine and Hyaluronidase (commonly used local anesthetic mixture) on the onset of block, quality of lid and globe akinesia, the duration of block, the possible complications and postoperative analgesia in extraconal block for cataract surgeries.

Patients and Methods: The study was conducted in the operating rooms of Ophthalmology Department, Zagazig University Hospitals.

Method: The sample size was calculated to be 38 patients divided into 2 groups (19 in each group). Using the open Epi, I program assuming that the mean of corneal sensation at 3 minutes in group of magnesium sulphate is (1.66 \pm 0.52$)$ and in standard group is $(2.00 \pm 0.00)$ (Mogahed et al., 2017). With a power of the test of $80 \%$ and a confidence interval of $95 \%$.

Results: there were no statistical significance differences between Group C and Group M in age or sex distribution. there was statistical significance increase in Sarvela score in Group C compared to group M in all times. Also, there were statistical significance differences between the different readings of each group. there was statistical significance increase in onset of Akinesia and decrease in duration of block among group C compared to Group M. Also, both groups had no perivalvular or sub tenon addition. there were no statistical significance differences between Group C and Group M in patient or doctor satisfaction. there were statistical significance differences between Group M and Group C in VAS score. Also, this table shows that there was statistical significance decrease in frequency of cases need post-operative analgesics need and increase in time after operation to need analgesic among Group M compared to Group C. But no statistical significance difference found between them in its dose. there were no statistical significance differences between Group C and Group M in frequency of complication.

Conclusion: We can conclude that magnesium sulphate can be added to ocular local anesthetics in the extraconal block to hasten the onset of the block and increase its duration without causing any side effects.

Keywords: Magnesium sulphate; Extraconal; Cataract

\section{Introduction}

Ocular surgeries may be performed under topical, regional or general anesthesia. The first recorded use of regional anesthesia for eye surgery was the instillation of cocaine into the conjunctival sac in 1884 by an Austrian ophthalmologist Karl Koller [1]. Later, a major change in anesthetic practice had taken place, as the majority of ophthalmic surgical patients now undergo regional rather than general anesthesia. This change has been driven in part by the desire to make surgical procedures as day case, also regional anesthesia involve less risk, easy to perform and is more economic [2]. Among regional blocks, peribulbar block is safer in comparison to retrobulbar block due to a lesser incidence of serious complications such as brainstem affection by anesthesia, globe perforation, and retrobulbar hemorrhage [3]. The performance of ocular anesthesia and akinesia with peribulbar block surly takes a longer time in comparison to retrobulbar block, so higher volume of local anesthetic is needed, thus thinking of giving additives added to LA drugs to enhance the onset and the duration of the block is recommended [4].

In 1949, Atkinson [5] reported the advantages of using Hyaluronidase in anesthetic solutions to achieve early akinesia and anesthesia in ophthalmic surgery, the Hyaluronidase catalysis the depolymerization of hyaluronic acid to a tetra saccharide and leads to liquefaction of gelatinous interstitial barrier [5]. It is thought to improve the efficacy of local anesthetic injections by breaking down the interstitial cell barrier, thereby facilitating diffusion of the anesthetic agent [6].

Indeed, one of the recent additives to local anesthetics in ophthalmic practice is Magnesium sulphate. Magnesium is a physiological calcium channel blocker and a noncompetitive antagonist of N-methyl-D-Aspartate (NMDA) receptors. It has 
been used with a local anesthetic solution in different regional anesthesia techniques to decrease the onset time of block and to increase the quality and duration of anesthesia [7]. Also, the high concentration of $\mathrm{Mg} 2+$ attracted is by the negative charges of the outer membrane surface affected $\mathrm{Na}+$ channel gating causing hyperpolarization and inhibition of nerve conduction as an anesthetic action [8].

Analgesic effects of magnesium sulphate on peripheral nerves may be due to the antagonism of NMDA receptors, thus preventing central sensitization from peripheral nociceptive stimulation. Also, magnesium competitively blocks calcium influx into presynaptic endings leading to reduced acetylcholine release. However, the surface charge theory is also another possible mechanism [9].

\section{Patients and Methods}

The study was conducted in the operating rooms of Ophthalmology Department, Zagazig University Hospitals. Sample size was calculated to be 38 patients divided into 2 groups (19 in each group). Using the open Epi, I program if the mean of corneal sensation at 3 minutes in group of magnesium sulphate is $(1.66 \pm 0.52)$ and in standard group is $(2.00 \pm 0.00)$. With a power of the test of $80 \%$ and a confidence interval of $95 \%$.

A-patients: The study included 38 patients undergoing cataract surgery who scheduled to receive peribulbar block.

a. Inclusion Criteria: Patients fulfilled all of the following criteria: Age range from 40 to 65 years old of both sex with physical status ASAI or II and undergoing unilateral cataract surgery.

b. Exclusion Criteria: Patients excluded from our study if one or more of the following criteria were present:

Refusal of the patient, patient with altered mental status, presence of infection at the injection site, presence of history of allergy to any of the used drugs or presence of history of coagulopathy or bleeding.

B-method: All patients were randomly divided into two groups (group C and group M) using computer generated randomization table; each group consisted of 19 patients (Figure 1).

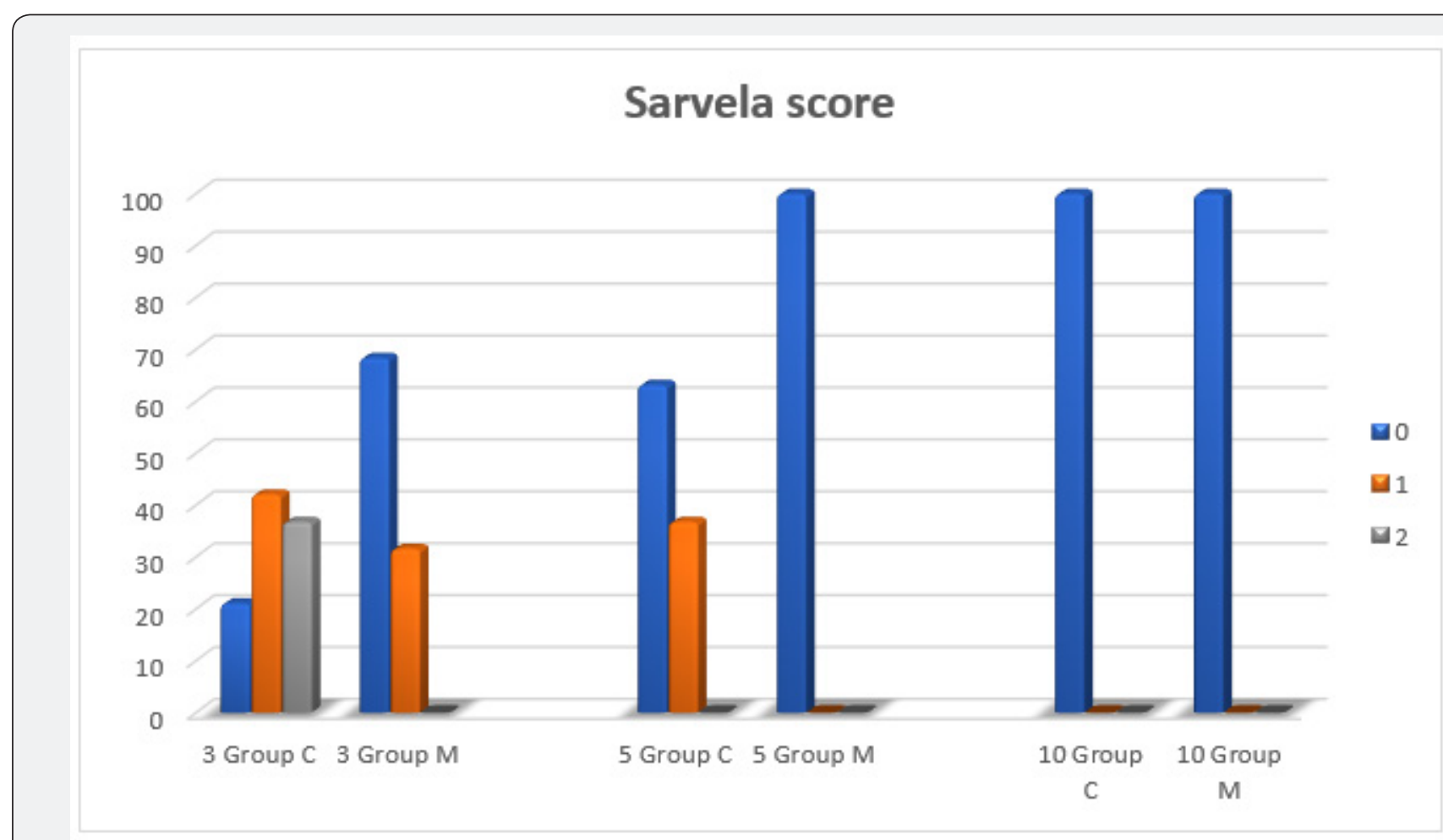

Figure 1: Comparison of Sarvela score of the two studied groups at different times.

\section{Intraoperative Management}

On arrival to the operating room, history of any medical disease, drugs taken, or previous operations was obtained from the patient, meanwhile, the arterial blood pressure was measured with an automated oscillometer, five leads electrocardiography was connected, and arterial oxygenation was measured by a pulse oximetry, and then a vein was cannulated (Table 1). Premedication, topical anesthesia or 86 sedation were not given at the time of the block or during the intraoperative period. Then the 38 Patients were randomized into two groups using a closed envelopes seal and the patients in each group received a total of $7 \mathrm{ml}$ solution for the peribulbar block. 
Table 1: Comparison of demographic data of the two studied groups.

\begin{tabular}{|c|c|c|c|c|c|c|}
\hline Variable & \multicolumn{2}{|c|}{$\begin{array}{l}\text { Group C } \\
\text { (Control) } \\
(\mathrm{n}=19)\end{array}$} & \multicolumn{2}{|c|}{$\begin{array}{c}\text { Group M } \\
\text { (Mg sulphate) } \\
\text { (n=19) }\end{array}$} & $\mathbf{t}$ & p \\
\hline \multicolumn{7}{|l|}{ Age: (years) } \\
\hline Mean \pm SD & \multicolumn{2}{|c|}{$59.74 \pm 5.19$} & \multicolumn{2}{|c|}{$58.58 \pm 7.03$} & \multirow{2}{*}{0.58} & 0.57 \\
\hline \multirow[t]{2}{*}{ Range } & \multicolumn{2}{|c|}{$50-65$} & \multicolumn{2}{|c|}{$40-65$} & & NS \\
\hline & No & $\%$ & No & $\%$ & $\chi^{2}$ & $\mathrm{P}$ \\
\hline \multicolumn{7}{|l|}{ Sex: } \\
\hline Male & 9 & 47.4 & 8 & 42.1 & \multirow{2}{*}{0.11} & 0.74 \\
\hline Female & 10 & 52.6 & 11 & 57.9 & & NS \\
\hline
\end{tabular}

SD: Standard Deviation

$\mathrm{t}$ : Independent $\mathrm{t}$ test

$\mathrm{X} 2$ : Chi square test

NS: Non-significant $(P>0.05)$

This table shows that there were no statistical significance differences between Group $\mathrm{C}$ and Group M in age or sex distribution.

Patients of Group C received a mixture of $4 \mathrm{ml}$ of lidocaine $2 \%$ including $120 \mathrm{IU}$ hyaluronidase $+2 \mathrm{ml}$ of bupivacaine $0.5 \%+1 \mathrm{ml}$ normal saline (total $7 \mathrm{ml}$ ). On the other hand, patients of Group C received a mixture of $4 \mathrm{ml}$ of lidocaine $2 \%$ including $120 \mathrm{IU}$ hyaluronidase $+2 \mathrm{ml}$ of bupivacaine $0.5 \%+0.5 \mathrm{ml}$ Magnesium Sulphate $(50 \mathrm{mg})$ and were completed to $1 \mathrm{ml}$ normal saline (total $7 \mathrm{ml}$ ). Taking in consideration that hyaluronidase was prepared by dissolving its powder (1500 IU) in the Lidocaine vial (50 ml) (Table 2). The patient was asked to fix his eyes looking straight forward toward the ceiling while lying in a supine position. A $10 \mathrm{ml}$ syringe

with a 25G needle was used for the local anesthetic injection. After negative aspiration, the first $5 \mathrm{ml}$ were slowly injected at the junction of the lateral one third and medial two thirds of the inferior orbital margin with the bevel directed towards the equator of the eye ball and the other $2 \mathrm{ml}$ were injected between the caruncle and the medial canthus. Intermittent gentle massage was applied for 10 minutes, and after satisfactory sensory and motor block, oxygen of $3 \mathrm{~L} / \mathrm{min}$ was delivered through a nasal cannula to the patient, then surgery was allowed to proceed (Table 3).

Table 2: Comparison of Sarvela score of the two studied groups at different times.

\begin{tabular}{|c|c|c|c|c|c|c|c|}
\hline \multirow[t]{2}{*}{ Time } & \multirow[t]{2}{*}{ Sarvela score } & \multicolumn{2}{|c|}{$\begin{array}{l}\text { Group C } \\
\text { (Control) } \\
(n=19)\end{array}$} & \multicolumn{2}{|c|}{$\begin{array}{c}\text { Group M } \\
\text { (Mg sulphate) } \\
(n=19)\end{array}$} & \multirow[t]{2}{*}{$\chi^{2}$} & \multirow[t]{2}{*}{$\mathbf{P}$} \\
\hline & & No & $\%$ & No & $\%$ & & \\
\hline \multirow{3}{*}{3} & 0 & 4 & 21.1 & 13 & 68.4 & \multirow{3}{*}{12.05} & \multirow{3}{*}{$0.002^{* *}$} \\
\hline & 1 & 8 & 42.1 & 6 & 31.6 & & \\
\hline & 2 & 7 & 36.8 & 0 & 0 & & \\
\hline \multirow{2}{*}{5} & 0 & 12 & 63.2 & 19 & 100 & 8.58 & $0.003^{* *}$ \\
\hline & 1 & 7 & 36.8 & 0 & 0 & -- & -- \\
\hline \multicolumn{2}{|c|}{ P! } & \multicolumn{2}{|c|}{$<0.001^{* *}$} & \multicolumn{2}{|c|}{$<0.001^{* *}$} & & \\
\hline
\end{tabular}

$\mathrm{X}$ 2: Chi square test

!: Fridman paired test

**: Highly significant $(P<0.01)$

This table shows that there was statistical significance increase in Sarvela score in Group C compared to group M in all times. Also, there were statistical significance differences between the different readings of each group. 
Table 3: Comparison of onset of akinesia \& duration of block among the two studied groups.

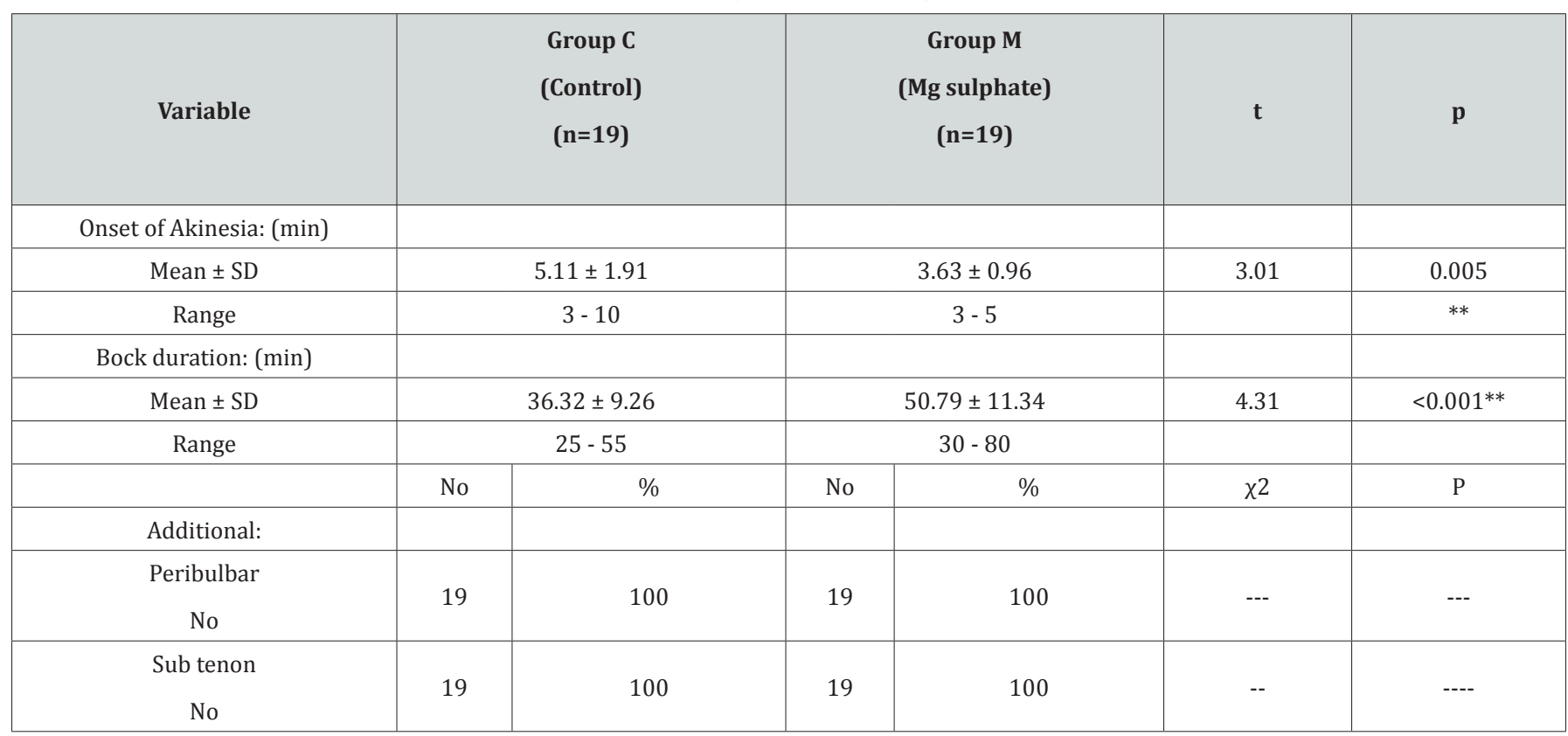

SD: Standard deviation

$\mathrm{t}$ : Independent $\mathrm{t}$ test

$\mathrm{X}$ 2: Chi square test

**: Highly significant $(P<0.01)$

This table shows that there was statistical significance increase in onset of Akinesia and decrease in duration of block among group $\mathrm{C}$ compared to Group M. Also, both groups had no perivalvular or sub tenon addition.

\section{Data Collection}

For each patient we obtained preoperative: Name, age (in years) and sex Physical state (ASA I and II), Hospital diagnosis. Type of surgery and Medical and surgical history (Table 4). This table shows that there were statistical significance differences between Group M and Group C in VAS score. Also, this table shows

Table 4: Patient \& doctor satisfaction among the two studied groups.

\begin{tabular}{|c|c|c|c|c|c|c|}
\hline \multirow[t]{2}{*}{ Variable } & \multicolumn{2}{|c|}{$\begin{array}{c}\text { Group II } \\
\text { (Control) } \\
(n=19)\end{array}$} & \multicolumn{2}{|c|}{$\begin{array}{c}\text { Group M } \\
\text { (Mg sulphate) } \\
(n=19)\end{array}$} & \multirow[t]{2}{*}{$\chi 2$} & \multirow[t]{2}{*}{$\mathbf{P}$} \\
\hline & No & $\%$ & No & $\%$ & & \\
\hline \multicolumn{7}{|l|}{ Patient: } \\
\hline 2 & 1 & 5.3 & 0 & 0 & \multirow{3}{*}{2.42} & \\
\hline 3 & 2 & 10.5 & 5 & 26.3 & & 0.30 \\
\hline 4 & 16 & 84.2 & 14 & 73.7 & & NS \\
\hline \multicolumn{7}{|l|}{ Doctor: } \\
\hline 2 & 2 & 10.5 & 0 & 0 & \multirow{3}{*}{2.67} & \\
\hline 3 & 2 & 10.5 & 4 & 21.1 & & 0.26 \\
\hline 4 & 15 & 79 & 15 & 78.9 & & NS \\
\hline
\end{tabular}

$X 2$ : Chi square test

NS: Non-significant $(P>0.05)$

This table shows that there were no statistical significance differences between Group C and Group M in patient or doctor satisfaction. 
Table 5: Post-operative VAS score and analgesic requirement among the two studied groups.

\begin{tabular}{|c|c|c|c|c|c|c|}
\hline Variable & \multicolumn{2}{|c|}{$\begin{array}{l}\text { Group C } \\
\text { (Control) } \\
(n=19)\end{array}$} & \multicolumn{2}{|c|}{$\begin{array}{c}\text { Group M } \\
\text { (Mg sulphate) } \\
\text { (n=19) }\end{array}$} & \multirow[t]{2}{*}{ MW } & \multirow[t]{2}{*}{$\mathbf{p}$} \\
\hline \multicolumn{5}{|l|}{ Vas score: } & & \\
\hline Mean \pm SD & \multicolumn{2}{|c|}{$0.42 \pm 0.69$} & \multicolumn{2}{|c|}{$0.23 \pm 0.56$} & \multirow{3}{*}{3.08} & \multirow{3}{*}{$0.030^{*}$} \\
\hline Median & & & & & & \\
\hline Range & \multicolumn{2}{|c|}{$0-2$} & \multicolumn{2}{|c|}{$0-2$} & & \\
\hline Variable & No & $\%$ & No & $\%$ & $\chi^{2}$ & $P$ \\
\hline \multicolumn{7}{|c|}{ Post-operative analgesic: } \\
\hline No & 9 & 47.4 & 15 & 78.9 & \multirow{2}{*}{4.07} & \multirow{2}{*}{$0.04^{*}$} \\
\hline Yes & 10 & 52.6 & 4 & 21.1 & & \\
\hline \multicolumn{7}{|l|}{ Time (h) } \\
\hline $2-3$ & 6 & 60 & 0 & 0 & \multirow{2}{*}{4.02} & $0.04^{*}$ \\
\hline $3.5-4$ & 4 & 40 & 4 & 100 & & \\
\hline \multicolumn{7}{|l|}{ Dose (unit) } \\
\hline 1 & 7 & 70 & 4 & 100 & 1.53 & 0.22 \\
\hline 2 & 3 & 30 & 0 & 0 & & NS \\
\hline
\end{tabular}

SD: Standard deviation

\section{MW: Mann Whitney}

\section{NS: Non-significant $(\mathrm{P}>0.05)$}

This table shows that there were statistical significance differences between Group M and Group C in VAS score. Also, this table shows that there was statistical significance decrease in frequency of cases need post-operative analgesics need and increase in time after operation to need analgesic among Group M compared to Group C. But no statistical significance difference found between them in its dose.

Table 6: Post-operative complication among the two studied groups.

\begin{tabular}{|c|c|c|c|c|c|c|}
\hline \multirow[t]{2}{*}{ Variable } & \multicolumn{2}{|c|}{$\begin{array}{c}\text { Group C } \\
\text { (Control) } \\
(n=19)\end{array}$} & \multicolumn{2}{|c|}{$\begin{array}{c}\text { Group M } \\
\text { (Mg sulphate) } \\
(n=19)\end{array}$} & \multirow[t]{2}{*}{$\chi^{2}$} & \multirow[t]{2}{*}{$\mathbf{P}$} \\
\hline & No & $\%$ & No & $\%$ & & \\
\hline \multicolumn{7}{|c|}{ Complication: } \\
\hline No & 16 & 84.2 & 19 & 100 & \multirow{2}{*}{3.26} & 0.07 \\
\hline Chemosis & 3 & 15.8 & 0 & 0 & & NS \\
\hline
\end{tabular}

\section{X2: Chi square test}

NS: Non-significant $(P>0.05)$

This table shows that there were no statistical significance differences between Group $C$ and Group $M$ in frequency of complication.

\section{Discussion}

A major change in anesthetic practice had taken place, as the majority of ophthalmic surgical patients now undergo regional rather than general anesthesia This change has been driven in part by the desire to make surgical procedures as day case, also regional anesthesia is involving less risk, easy to perform and more economic. Among regional blocks, peribulbar block is safer in comparison to retrobulbar block due to a lesser incidence of serious complications such as brainstem affection by anesthesia, globe perforation, and retrobulbar hemorrhage.

But unfortunately, the performance of ocular anesthesia and akinesia with peribulbar block takes a longer time in comparison to retrobulbar block so higher volume of local anesthetic is needed, thus thinking of giving additives added to LA drugs to enhance the onset and the duration of the block is recommended. Magnesium sulphate is a recent one of these additives, as the magnesium is a physiological calcium channel blocker and a noncompetitive antagonist of N-methyl- D-aspartate (NMDA) receptors so it has been used with a local anesthetic solution in different regional anesthesia techniques to decrease the onset time of block and to increase the quality and duration of anesthesia.

In these studies, we compared the effect of adding magnesium sulphate to commonly used ocular local anesthetics (Lidocaine and bupivacaine) and adjuvant (hyaluronidase) for peribulbar 
block for patients undergone cataract surgeries as regard onset of motor and sensory akinesia, postoperative analgesia, rescue analgesic requirements and the possible complications. As regarding the hemodynamics (BP, HR and SPO2) these studies showed no significant difference between both group and also show no significant differences all through the operation in both group that mean that addition of magnesium has no effect on the patient hemodynamics.

These result are in agreement with Mogahed et al. who compared the effect of adding two different doses of magnesium sulphate $(50 \mathrm{mg}$ and $100 \mathrm{mg}$ ) as adjuvant to ropivacaine in peribulbar block for cataract surgery in their study they measured the blood pressure and 02 saturation at $(5,10,30$ and 60 minutes) and found no significance hemodynamic effect of addition of magnesium in different doses (50 mg and $100 \mathrm{mg}$ ). As regard the onset of the motor and the sensory akinesia, the current study revealed significant difference between both group $(\mathrm{p}<0.005)$ as patients of group $M$ showed earlier motor block as 13 patients reached sarvela score 0 within only 3 minutes and all the remaining patients of the group reached sarvela 0 at 5 minutes but in contrast only 4 patients of group C reached sarvela 0 at 3 minutes and another 8 patients reached it at 5 minutes and the last 7 patients take 10 minutes to reach sarvela 0 . Also, all patients of group $\mathrm{M}$ showed loss of corneal sensation within the first 5 minutes, but some patients of group $\mathrm{C}$ needed 10 minutes for complete loss of corneal sensation.

These result in agreement with the study of Mogahed et al. who found that there is significant enhancement of the motor and sensory blocks between the three groups; mean score of motor movement of the four ocular muscles was $6.31 \pm 2.26$ in the group(control), $3.13 \pm 0.78$ in group $(50 \mathrm{mg}$ ) and $2.44 \pm 0.96$ in group $(100 \mathrm{mg})$, but after $5 \mathrm{~min}$ it was $1.06 \pm$ in the first group while the second and third groups showed complete motor block and also found that the mean score of lid squeezing of the $1.80 \pm$ 0.40 in the group (control), $0.84 \pm 0.36$ in group ( $50 \mathrm{mg}$ ) and 0.86 \pm 0.34 in group(100 mg), but after $5 \mathrm{~min}$ it was $2.8 \pm 0.50$ in the first group while the second and third groups showed complete motor block. At $2 \mathrm{~min}$, complete block of the corneal sensation occurred in group III, and at 3 min in group II. So, he found that the optimal time to start surgery was shorter in group III $(3.77 \pm 0.42$ $\mathrm{min})$, and group II (3.93 $\pm 0.25 \mathrm{~min}$ ) in comparison with group I $(6.51 \pm 2.75 \mathrm{~min})$.

Also, our result in agreement with Sinha et al. who found that the onset of globe and lid akinesia was statistically faster in the magnesium Group as compared to the control group in the first 10 min after the block. There was no difference for the globe and lid akinesia between the two groups at 15 and $20 \mathrm{~min}$. Also the result in agreement with Abd El-Hamid, who evaluated the effect of adding magnesium sulphate versus clonidine as adjunct to local anesthetic during peribulbar block and revealed that the onset of eye lid akinesia was more rapid in group $\mathrm{M}$ rather than the two other groups (X2 = 11.6; $\mathrm{P}>0.05),(\mathrm{X} 2=11.6$; $\mathrm{P}>0.05)$ and that the onset of eye globe akinesia was more rapid in group $\mathrm{M}$ rather than the two other groups $(\mathrm{X} 2=21.1 ; \mathrm{P}<0.05)$.

But our result in disagreement with Abu Elyazed \& Mostafa, who found that the addition magnesium sulphate to local anesthetic solution for peribulbar block had no effect in their onset or in the quality of block by comparing the preoperative globe akinesia score among three groups(control, fentanyl and magnesium) founding that at $1 \mathrm{~min}, 3 \mathrm{~min}, 5 \mathrm{~min}$ and $8 \mathrm{~min}$ after the block, globe akinesia score was significantly lower in fentanyl group as compared to control $(\mathrm{P}<0.05)$ and magnesium sulphate groups $(\mathrm{P}<0.05)$ while there was no statistical difference between control and magnesium sulphate groups $(\mathrm{P}>0.05)$. Also our result matched with result from Abd El-Raouf et al. study who evaluated the effect of using magnesium sulphate as an adjuvant to regional anesthesia for ophthalmic surgery using peribulbar block and found that the onset of globe akinesia the magnesium sulphate groups (50mg) had a faster onset compared to control group and also the onset of akinesia was significantly faster for Group M50 where $60 \%$ of the cases got globe akinesia after 1 minute scored 0 and the remaining $40 \%$ scored 1 but when group $\mathrm{C}$ were evaluated after one minute, all cases scored 2 then found that for all cases to reach complete block (100\%) akinesia it took 3 minutes for group M50 and 5 minutes for control group.

Regarding the need of additional peribulbar block or sub tenon our study revealed no statistical significance as neither of patients of both groups need any additional block. These results matched with the result of Mogahed et al. who revealed no need for giving any additional local anesthesia in patients of all the three groups (control, $50 \mathrm{mg}$ magnesium and $100 \mathrm{mg}$ magnesium). Also, our result is in agreement with Sinha et al., who found that No patient required any supplemental injection for inadequate block.

These results are in disagreement with the result of Zein Elabdein \& Genidy study who found that there was significant high incidence of patients who required 2nd injection in the control group (group I) in comparison to the other two groups (group II and group III). As regard the duration of sensory and motor akinesia our study revealed highly significant increase in duration of block among group $\mathrm{M}$ in comparison to group $\mathrm{C}$ as group $\mathrm{M}(\mathrm{P}<0.001)$. These results correlated to the result of Abu Elyazed \& Mostafa [9], study who found that both fentanyl and magnesium sulphate significantly prolonged the duration of lid and globe akinesia compared to the control group $(\mathrm{P}<0.05)$ while the difference between them was statistically insignificant $(\mathrm{P}>0.05)$.

Also, these results agreed with the result of Abd El-Raouf et al., who found that the time to full recovery of motor power was significantly longer in Group M50 (5.3 $\pm 0.8, \mathrm{p}<0.001)$ compared to the control group suggesting that the addition of magnesium to local anesthetic mixture showed clinical and statically significance in duration of motor block. But these results disagreed with Abd El-Hamid, who found that clonidine group show prolongation in duration of globe and lid anesthesia and akinesia which was 
highly significant $(\mathrm{P}<0.05)$ in comparison to magnesium group which showed no effect on the duration. As regard the VAS score and the post-operative analgesic requirement our study showed significant decrease in the VAS score, prolongation in the postoperative analgesia and decrease in number of NSAIDS doses given postoperatively among group $\mathrm{M}$ in comparison with group C.

These results matched with Mogahed et al. results who found that post-operative pain score at $4 \mathrm{~h}$ and total amount of postoperative analgesia given in control group was significantly higher than both groups (50 mg) and (100mg) of magnesium and 2 postoperative pain score at $6 \mathrm{~h}$, control group was significantly higher than both group (50mg) and $(100 \mathrm{mg}$ ) and also group (50mg) was higher than group (100mg).

Also, these result in agreement with result of Abu Elyazed \& Mostafa [9], who found that there was no significant difference between the 3 groups regarding according to the postoperative pain score at the end of surgery, at $1 \mathrm{~h}$ and at $2 \mathrm{~h}$ postoperatively while regarding the postoperative pain score at $6 \mathrm{~h}$, group I was significantly higher than both group II and III and also group II was higher than group III. Also, in agreement with Abd El-Raouf et al. who found that the addition of $50 \mathrm{mg}$ magnesium to local anesthetic mixture showed clinical and statically significance delayed in first time to require rescue analgesia than control group and that the VAS score of postoperative pain was significantly lower in Group M50 compared to control group immediately after surgery and after 6 hours $(p<0.001)$. These results are also in agreement with Abd El-Hamid, who showed statistically significant difference between the control group and the other two groups as regard the median VAS at 1, 2, 3, 4, 5, 6 hours as control group had higher median pain score than the other two groups.

As regard the patient satisfaction our study showed nonsignificance differences between both groups as 16 patients of group C give score 4, 2 give score 3 and only 1 give score 2 in the same time 14 patients in group M give score 4 and 3 patients give score 3. These results disagreed with Zein Elabdein \& Genidy, who found that there was significant increase in patient satisfaction among magnesium (group II) and dexmedetomidine (group III) in comparison to the control group (group). As regard the doctor satisfaction our study showed also non-significance differences between both groups as 15 patients of group C give score 4, 2 give score 3 and 2 give score 2 in the same time 15 patients in group $M$ give score 4 and 4 patients give score 3 .

These results matched with result of Sinha et al. who found that surgeon's satisfaction score was similar regarding to the quality of anesthesia and surgical conditions in both the groups. These results disagreed with Zein Elabdein \& Genidy who found that there was significantly increase in the doctor satisfaction as the incidence of perfect block was significantly higher in magnesium (group II) and dexmedetomidine (group III) in comparison to the control group (group I). As regard the complications our study showed no significant complication in both groups only 3 cases in group control developed chemosis at site of injection most probably due to local allergic reaction. These results matched with Sinha et al., who found that there were no additional complications apart from chemosis which may be attributed to peribulbar block. Also, these results agreed with Abd El-Raouf et al. who found that magnesium sulphate in a dose of $50 \mathrm{mg}$ is a safe adjunct to local anesthetic in peribulbar block. Also matched with Abu Elyazed \& Mostafa [9] results who found no major complication in magnesium group only 1 patient complained of dizziness and 1 patient complained of pain during injection.

\section{Conclusion}

From the results of our study, we can conclude that magnesium sulphate can be added to ocular local anesthetics in the peribulbar block to hasten the onset of the block and increase its duration without causing any side effects. We recommend using magnesium as an additive to ocular local anesthetics to fasten its onset, prolong its duration and prolong the postoperative analgesia. Further studies should be done, to show whether adding higher doses of magnesium sulphate could hasten the onset and prolong the duration of anesthesia or not.

\section{References}

1. Goerig M, Bacon D, Van Zundert A (2012) Carl Koller, cocaine, and local anesthesia: Some less known and forgotten facts. Reg Anesth Pain Med 37(12): 318-324.

2. Riad W, Akbar F (2012) Ophthalmic regional blockade complication rate: A single center audit of 33,363 ophthalmic operations. J Clin Anesth 24(3): 193-195.

3. Rubin AP (1995) Complications of local anaesthesia for ophthalmic surgery. Br J Anaesth 75: 93-96.

4. Wong DH (1993) Regional anesthesia for intraocular surgery. Can J Anesth 40: 635-657.

5. Gupta CRP, Kapoor MG (2006) Safety and Efficacy of Sodium Bicarbonate versus Hyaluronidase in Peribulbar Anaesthesia. Med J Armed Forces India 62(2): 116-118.

6. Crawford M, Kerr WJ (1994) The effect of hyaluronidase on peribulbar block. Anaesthesia 49(10): 907-908.

7. Do SH (2013) Magnesium: A versatile drug for anesthesiologists. Korean J Anesthesiol 65(1): 4-8.

8. Lee AR, Yi HW, Chung IS, Ko JS, Ahn HJ (2012) Magnesium added to bupivacaine prolongs the duration of analgesia after interscalene nerve block. Can J Anesth 59(1): 21-27.

9. Abu Elyazed MM, Mostafa SF (2012) Fentanyl versus magnesium sulphate as adjuvant to peribulbar anesthesia in cataract surgery. Egyptian Journal of Anesthesia 33(2): 159-163. 

CC (i) This work is licensed under Creative BY DOI: 10.19080/JAICM.2018.07.555719
Your next submission with Juniper Publishers will reach you the below assets

- Quality Editorial service

- Swift Peer Review

- Reprints availability

- E-prints Service

- Manuscript Podcast for convenient understanding

- Global attainment for your research

- Manuscript accessibility in different formats

( Pdf, E-pub, Full Text, Audio)

- Unceasing customer service

Track the below URL for one-step submission https://juniperpublishers.com/online-submission.php 